\title{
Investigation of Rift Valley Fever Virus Infection Serologically and Pathologically in Aborted Cattle, Sheep, Goats and in Fetuses
}

\section{Mehmet Kale ${ }^{1 *}$, Sibel Hasircioglu ${ }^{1}$, Özlem Özmen ${ }^{2}$, Nuri Mamak ${ }^{3}$, Sibel Gür ${ }^{4}$, Orhan Yapici ${ }^{5}$, Sibel Yavru ${ }^{5}$, Mehmet Haligür ${ }^{6}$, Oya Bulut ${ }^{5}$, Kamil Atli ${ }^{1}$ and Yakup Yildirim ${ }^{1}$}

\footnotetext{
${ }^{1}$ Department of Virology, Faculty of Veterinary Medicine, Burdur Mehmet Akif Ersoy University, Burdur, Turkey.

${ }^{2}$ Department of Pathology, Faculty of Veterinary Medicine, Burdur Mehmet Akif Ersoy University,

${ }^{3}$ Department of Internal Medicine, Faculty of Veterinary Medicine, Burdur Mehmet Akif Ersoy University, Burdur, Turkey.

${ }^{4}$ Department of Virology, Faculty of Veterinary Medicine, Afyon Kocatepe University, Afyonkarahisar, Turkey.

${ }^{5}$ Department of Virology, Faculty of Veterinary Medicine, Selcuk University, Konya, Turkey. ${ }^{6}$ Department of Pathology, Faculty of Veterinary Medicine, Cukurova University, Ceyhan, Adana,
}

Turkey.

\section{Authors' contributions}

This work was carried out in collaboration among all authors. All authors read and approved the final manuscript.

Article Information

DOI: 10.9734/ARRB/2020/v35i130174

Editor(s):

(1) Antony Radol, Kenya.

(2) Abdusalam Sharef Mahmoud, University of Pisa, Italy.

Reviewers:

(1) Paola Angelini, University of Perugia, Italy

Complete Peer review History: http://www.sdiarticle4.com/review-history/53828

Original Research Article

Received 10 November 2019

Accepted 18 January 2020

Published 14 March 2020

\section{ABSTRACT}

In this study, Rift Valley Fever Virus (RVFV) infection was searched serologically and pathologically in cattle (178 Holstein), sheep (160 native), goats (66 ordinary goats, 98 Honamli goats, 16 Saanen goats) with an abortion history and in unborn cattle (8), sheep (24) and goat (5) fetus. Samples were collected between July 2009 and September 2010. As a result of studying specific antibodies to

*Corresponding author: E-mail: drmkalex@yahoo.com; 
RVFV by using the c-ELISA method in blood serum samples collected from cattle, sheep and goats suffering abortion, seropositivity was identified in 7 cattle $(7 / 178 ; 3.93 \%), 4$ sheep $(4 / 160 ; 2.50 \%)$ and 18 goats (18/180;10.0\%). 18 seropositive goats were distributed according to race as 13 ordinary goats $(19.70 \%), 2$ Honamli goats $(2.04 \%)$ and 3 Saanen goats $(18.75 \%)$. When liver, spleen and brain samples of the unborn fetus of cattle, sheep and goats were studied histopathologically, no pathological findings on RVFV disease were obtained. Consequently, in this study, where RVFV infection in cattle, sheep and goats raised in Western Mediterranean Region of Turkey was serologically revealed, it was concluded that RVFV did not take place in the aetiology of abortion cases in relevant species.

Keywords: Rift valley fever virus; serology; pathology; abortion; domestic animal.

\section{INTRODUCTION}

Rift Valley Fever (RVF) is a zoonotic viral disease caused by an RNA virus located in Phlebovirus genus from Bunyaviridae family $[1,2]$. The virus was identified from sheep suffering from sudden death and abortion around Naivasha Lake located in Great Rift Valley in Kenya in 1930 [3]. Rift Valley Fever Virus (RVFV) has two strains defined as Zinga virus isolated in the Republic of Central Africa in 1969 and Lunyo virus isolated in Uganda within the same year [4]. RVFV causes infection in cattle, sheep, goats, camels, rodents, primates, ferrets, cats and dogs. Besides, RVFV might also cause experimental infections in rabbits, cavies, birds, horses, pigs and other animals [1]. The disease is mostly seen in farm animals and humans [5].

RVFV is transmitted to mammalian hosts by infected mosquitoes such as Aedes, Culex, Mansonia, Eretmapodites and Coquillettidia [6]. Epidemic risk is higher between July and September when vectors are active. During autumn, even though there is a risk of epidemics, epidemics last short due to the fall in the number of mosquitoes [7].

During infection, encephalitis, hepatitis, retinitis, rhinitis and complications such as hemorrhagic fever and death in more severe cases can be seen in humans [8]. The death rate in humans has been reported as between $0.5 \%$ and $2 \%$ due to icterus, neurosis and hemorrhagic diseases [9]. Fever, lacrimation, nasal flow, pain, vomiting and bloody diarrhoea can be seen in mature domestic ruminants while abortion is commonly seen in pregnant animals [10]. Infections depending on abortions might be seen in pregnant ruminants infected by RVFV. A disease statement might also appear varying from fetal malformation and subclinical to fatal inflammatory diseases. Most of the lambs born in this period die of acute hepatitis $[3,11,12]$. In lambs and calves, the disease suddenly begins following an incubation period of about 12 hours. The infected animals manifest high fever, icterus, depression, lack of coordination and collapse. Lambs and yearlings are the most sensitive animals against RVFV $[4,13]$. The agent causes symptoms in newborn calves like the clinical findings seen in lambs. The incoming animals into the herd might be easily infected by the existing virus [4]. Death is seen within 36 hours in $95-100 \%$ of lambs and $70 \%$ of calves infected by the disease [13]. Infection signs in goats resemble those in sheep. Even though the low mortality rate is reported in goats, it can be higher as $20-30 \%$ in sheep and $10 \%$ in cattle [6].

Lesions are limited to the liver and characterized by focal hepatic necrosis. The liver is fragile in necropsy and has slight growth, soft, pale and subcapsular bleeding centres [6]. Petechia and congestions can be seen in the gastrointestinal system, heart, gall bladder and lymph nodes [13].

In diagnosing RVF infection, serological tests such as virus neutralization, hemagglutination inhibition (HAI), plaque reduction neutralization (PRN), complement fixation (CF), indirect immunofluorescence assay (IFA) and ELISA can be used as well as virological and molecular methods $[14,15,16,17]$.

In this study, we aimed to search the presence /prevalence of RVFV infection in cattle, sheep and goats raised in the Western Mediterranean region of Turkey.

\section{MATERIALS AND METHODS}

\subsection{Animal Materials}

The material for this study included 518 blood serum and 37 abort fetus from different animal species between July 2009 and September 2010. In the study, RVFV infection was investigated serologically and pathologically in cattle (178 Holstein), sheep (160 native race), 
goats (66 ordinary goats, 98 Honamli goats, 16 Saanen goats) with an abortion history and in unborn cattle (8), sheep (24) and goat (5) fetus.

\subsection{Histopathological Methods}

At necropsy of fetuses, tissue samples were collected and fixed in 10\% neutral formalin solution, processed through graded alcohols and xylene, embedded in paraffin and sectioned at 5 $\mu \mathrm{m}$. Slides were stained with hematoxylin \& eosin $(H \& E)$ and examined under the light microscope.

\subsection{Competitive Enzyme-Linked Immuno- sorbent Assay (c-ELISA)}

For detection of RVF virus antibodies, a competitive ELISA system (ID VET, Product code: RIFTC, Multi-species, Montpellier-France) was used. Tests were performed according to the manufacturer's directions. Briefly, $50 \mu$ of test sera and controls diluted at 1:2 in dilution buffer were added to each well. Following 45minute incubation at $37^{\circ} \mathrm{C}$, all wells were washed three times and Anti-RVF-NP-Po conjugate was added in all wells as $100 \mu \mathrm{l}$. Washings were reperformed after 30 -minute incubation at $21^{\circ} \mathrm{C}$. In the final step, $100 \mu \mathrm{l}$ substrate solution tetramethylbenzidine (TMB) was added to each well and incubated for 15 minutes at $21^{\circ} \mathrm{C}$ and reaction was stopped by adding $100 \mu \mathrm{l} 0.5 \mathrm{M}$ $\mathrm{H}_{2} \mathrm{SO}_{4}$. The results were evaluated by reading the plates in ELISA reader at $450 \mathrm{~nm}$.

\subsection{Statistical Analysis}

The statistical analysis of absorbance was performed by using Statistical Package for Social Sciences software (IBM SPSS Statistics 20.0, SPSS inc., Chicago, IL, USA). Proportional differences between species were evaluated using $\left(x^{2}\right)$ test. At the end of the studies, data found as $P<0.05$ was accepted as significant.

\section{RESULTS}

\subsection{Distribution of Seropositivity Selected Animal Species}

In this study, RVFV specific antibody presence was investigated by C-ELISA method in 518 samples. The highest seropositivity was observed in goat species at $10 \%(18 / 180$, followed by cattle at $3.93 \%(7 / 178)$ and the least seropositivity found in sheep at $2.50 \%(4 / 160)$ (Table 1).

\subsection{Distribution of Seropositivity among Goat Species}

The distribution of 18 seropositive goat samples between races was found as 13 ordinary goats, 2 Honamli goats and 3 Saanen goats. (Table 2).

Table 1. Obtained RVFV seropositivity rates of sampled species

\begin{tabular}{llll}
\hline Species & Number of & \multicolumn{2}{c}{ RVFV } \\
\cline { 3 - 4 } & samples & Antibody (+) & (\%) \\
\hline Cattle & 178 & 7 & 3.93 \\
Sheep & 160 & 4 & 2.50 \\
Goats & 180 & 18 & 10 \\
Total & $\mathbf{5 1 8}$ & $\mathbf{2 9}$ & $\mathbf{5 . 6 0}$ \\
\hline
\end{tabular}

Table 2. Distribution of RVFV seropositivity in goat races

\begin{tabular}{llll}
\hline Race & $\begin{array}{l}\text { Number of } \\
\text { samples }\end{array}$ & \multicolumn{2}{c}{ RVFV } \\
\cline { 3 - 4 } & Antibody (+) & (\%) \\
\hline Ordinary & 66 & 13 & 19.70 \\
Honamli & 98 & 2 & 2.04 \\
Saanen & 16 & 3 & 18.75 \\
Total & $\mathbf{1 8 0}$ & $\mathbf{1 8}$ & $\mathbf{1 0}$ \\
\hline
\end{tabular}

During the histopathological examination, hyperemia and slight haemorrhages in the visceral and central nervous system organs were commonly observed. Also, slight neutrophil leukocyte and lymphocyte infiltration were observed in sections. Autolytic changes were common especially if fetus died long before the abortion. There were no inclusion bodies, in any case, any organ.

At the end of statistical evaluations, the difference between seropositivity value in cattle and the value in sheep was detected as statistically insignificant $(p>0.05)\left(x^{2}=0.549\right.$, $p=0.459)$ whereas the difference between cattle and goats was statistically significant $(p<0.05)$ $\left(x^{2}=5.072, p=0.024\right)$. Similarly, the value difference between sheep and goats was highly significant $(p<0.05)\left(X^{2}=7.873, p=0.005\right)$.

\section{DISCUSSION}

\subsection{Discuss the Implication of Distribu- tion of Positivity}

High seropositivity in species: RFV infection, which is a very important veterinary public health problem, was first seen in rural Africa. The 
disease is transmitted by arthropod vectors in irregular intervals. Climate changes especially in this continent and irregular large epidemic due to changes in irrigation systems along the River Nile threaten animal and human health. The agent has sustained its geographical distribution frequently until today [4]. The disease, historically originating in Africa Continent, has spread around the Arabian Peninsula and the Indian Ocean recently $[18,19]$. Legal and illegal animal movements in these regions contribute to the viral distribution and threaten Mediterranean Basin. The fact that RVF infection was seen in the Middle East, Northern Egypt and Comor Islands caused worries for an increase in geographical distribution and a possible epidemic in Europe and even Northern America [18].

Previous studies showed that among hemorrhagic fevers, RVF infection was the most connected one with climatic changes. In 2010 in Sudan, Adam et al. [20] performed a study on RVF infection progressing with clinical symptoms such as fever, bleeding and icterus and causing deaths and found acute RVF indicators, the IgM antibodies in six of 18 patients and many clinical findings. In other studies performed in Sudan and Mayotte, presence of RVF virus was also revealed molecularly $[19,21,22]$. In another study in Tunisia, in samples collected from 181 fever patients and healthy-looking 38 humans without fever symptoms working in slaughterhouse/ agriculture, RVF infection was serologically investigated and an antibody positivity was detected at $8.3 \%(n=15)$ in fever patients and $7.8 \%(n=3)$ in humans in the other group [14]. In Saudi Arabia, another country in Africa continent, at the end of investigating 2322 human blood serum samples with serological methods, an RVF seropre valence was found at the rate of $6 \%$ $(n=139)$ [23].

Circulation of RVF disease continues, although virus titer is low for animals and vector mosquitoes. In some studies, epidemics were proved to appear in endemic areas for them to exist without dense seasons of precipitation. However, when satellite and atmosphere pictures were examined parallelism between seasons of precipitation and the incidence of disease in areas where RVF infection was endemic was established [4].

High seropositivity in goat subspecies: Since differential diagnosis could not be performed promptly in case of mixed infections at times, diagnosis of RVF infection could go unnoticed.
Other viral diseases causing hemorrhagic disease statements, particularly Salmonella, Pasteurella and Anthrax, were the most concerned infections [4].

Many lab methods have been used to diagnose RVF infection. However, in performed studies, ELISA technique has were proved to have been highly sensitive in herd scanning compared to other serological tests $[15,17]$. Scott et al. [17] detected specificity and sensitivity rate of ELISA test as $100 \%$ in serological testing of RVF infection.

Research has been carried out in many countries in the case of the disease in animals. Ahmed et al. [24] detected RVF antibody positivity as $43 \%$ in small ruminants and $33 \%$ in camels in their study in a Northwestern African country, Mauritania. In Namibia, within sheep and goat herds, the nucleic acid of RVF virus was shown by molecular methods in autopsy materials of animals showing various clinical symptoms [25]. Jackel et al. [15] found seropositivity at a rate of $20.59 \%$ using ELISA method in 1952 sheep $(n=900)$ and goat $(n=1052)$ blood serum they collected from Mozambique, Uganda, Senegal and Yemen. Scott et al. [17] found RVF seropositivity at a rate of $5.74 \%$ in their study they performed on sheep located in Nile Delta. Rissmann et al. [16] stated that the infection progressed at the rates of $3.4 \%$ in small ruminants and $13.5 \%$ in cattle in Cameroon. In the same study, viremia was also detected by molecular methods in one small ruminant and three cattle. In their study in a Western country, Ivory Coast, Kanouté et al. [26] detected RVF antibody positivity at the rates of $3.9 \%$ in cattle and $2.4 \%$ in sheep. In the same study, the rate of abortion among sheep was found higher in the seropositive group. In the serological scanning using ELISA test performed in Gabon, another country in Africa, RVF seroprevalence was detected at the rate of $6.47 \%$ in small ruminants [27]. In this study, during statistical analysis, race and gender were not considered important for the prevalence of infection.

Limited research has been carried out on RVFV in Turkey. In their study on ruminant unborn fetus and many various species of domestic farm animals around northern areas of Turkey, Albayrak and Ozan $[28,29]$ did not encounter any RVF infection. Yılmaz et al. [30] found RVF infection seronegative in their study on sheep around Kars region. Only Gür et al. [31] detected RVF seropositivity at the rates of $8.5 \%$ in water 
buffalo blood serum $(35 / 410)$ and $1.3 \%$ in serum (1/71) they collected from Central Anatolia and Central Black Sea regions. In our study, we found the presence of RVF antibodies in blood serum samples from aborted cattle, sheep and goats, however, no findings on the relevant infection were seen during histopathological examinations in cattle, sheep and goat unborn fetus samples. Therefore, it is a correct approach to control aborted cattle, sheep and goats in terms of other viral and bacterial agents causing abortion.

In our study, when we statistically evaluated the difference between seropositivity rates we found among species at various rates, we concluded that especially high antibody positivity rate for goats was much higher than those of cattle and sheep. It was considered that this was because goats had a high possibility to encounter vector flies of RVF infection because they were feeding freely in pastures.

\section{CONCLUSION}

Consequently, the data obtained in this study, where presence/prevalence of RVF infection was considered for animals suffering abortion, would set up a substructure for other studies to be carried out on this topic, provide literature data and enable control of the disease. In areas where the disease is seen endemically, monitoring precipitation periods efficiently and taking precautions might prevent new epidemics. This method was tried in Somalia and Kenya in 1997 and the results were satisfactory. In countries where RVF infection is seen, national and regional monitoring and evaluation programs must be applied and investments put in place to develop new, safe and strong drugs and effective vaccines. Besides, breaking the transmission cycle of the disease, vector combat, using cube trucks for transporting farm animals and informing farmers about RVF infection is highly important to fight the disease.

\section{ETHICAL APPROVAL}

As per international standard, written ethical approval has been collected and preserved by the authors.

\section{ACKNOWLEDGEMENT}

This study has been carried out by permission of Ministry of Food, Agriculture and Livestock, General Directorate of Food and Control dated 08 February, 2013 in accordance with permission number 55016929-045.01/539.

\section{COMPETING INTERESTS}

Authors have declared that no competing interests exist.

\section{REFERENCES}

1. Ikegami T, Makino S. The Pathogenesis of Rift Valley Fever. Viruses. 2011;3:493519.

2. Xu F, Liu D, Nunes MR, Rosa AP, Tesh $\mathrm{RB}$, et al. Antigenic and genetic relationships among rift valley fever virus and other selected members of the genus Phlebovirus (Bunyaviridae). Am J Trop Med Hyg. 2007;76:1194-1200.

3. Daubney R, Hudson JR, Garnham PC. Enzootic hepatitis or rift valley fever. An undescribed virus disease of sheep, cattle and man from East Africa. J Pathol Bacteriol. 1931;34:545-579.

4. Howard CR. Rift Valley Fever. In: Zuckerman AJ, Mushahwar IK editors, Viral haemoorrhagic fevers. Amsterdam: Elsevier Science; 2004.

5. Olive MM, Goodman S, Reyne JM. The role of wild mammals in the maintenance of rift valley fever virus. J Wildl Dis. 2012; 48:241-266.

6. Smith MC, Sherman DM. Goat Medicine, lowa: Wiley-Blackwell Publishing; 2009.

7. Fischer EA, Boender G, Nodelijk G, Koeijer AA, Roermund HJW. The transmission potential of Rift Valley fever virus among livestock in the Netherlands: A modelling study. Vet Res. 2013;44:58.

8. Mohamed M, Mosha F, Mghamba J, Zaki $\mathrm{SR}$, Shieh WJ, et al. Epidemiologic and clinical aspects of a Rift Valley fever outbreak in humans in Tanzania, 2007. Am J Trop Med Hyg. 2010;83:22-27.

9. Pepin M, Bouloy M, Bird BH, Kemp A, Paweska J. Rift Valley fever virus (Bunyaviridae: Phlebovirus): An update on pathogenesis, molecular epidemiology, vectors, diagnostics and prevention. Vet Res. 2010;41:61.

10. Chengula AA, Kasanga CJ, Mdegela RH, Sallu R, Yongolo M. Molecular detection of Rift Valley fever virus in serum samples from selected areas of Tanzania. Trop Anim Health Prod. 2014;46:629-634.

11. Easterday BC. Rift valley fever. Adv Vet Med. 1965;10:65-127.

12. Findlay GM, Daubney R. The virus of rift valley fever or enzootic hepatitis. Lancet. 1931;221:1350-1351. 
13. Radositist OM, Gay CC, Hinchcliff $\mathrm{KW}$, Constable PD. Veterinary Medicine. A Textbook of the diseases of cattle, horses, sheep, pigs and goats. Philadelphia: Saunders; 2006.

14. Bosworth AT, Ghabbari S, Dowall A, Varghese W, Fares $R$, et al. Serologic evidence of exposure to rift valley fever virus detected in Tunisia. New Microbes New Infect. 2016;9:1-7.

15. Jackel $S$, Eiden $M$, Balkema-Buschmann A, Ziller M, Vuren PJV, et al. A novel indirect ELISA based on glycoprotein $\mathrm{Gn}$ for the detection of IgG antibodies against Rift Valley fever virus in small ruminants. Res Vet Sci. 2013;95:725-730.

16. Rissmann M, Eiden M, Wade A, Poueme $R$, Abdoulkadiri $S$, et al. Evidence for enzootic circulation of rift valley fever virus among livestock in Cameroon. Acta Trop. 2017;172:7-13.

17. Scott RM, Feinsod FM, Allam IH, Ksıazek TG, Peters CJ, et al. Serological tests for detecting Rift Valley Fever viral antibodies in sheep from the Nile Delta. J Clin Microbiol. 1986;24:612-614.

18. Mansfield KL, Banyard AC, McElhinney L, Johnson N, Horton DL, et al. Rift valley fever virus: A review of diagnosis and vaccination and implications for emergence in Europe. Vaccine. 2015;33:5520-5531.

19. Sissoko D, Giry C, Gabrie P, Tarantola A, Pettinelli $F$, et al. Rift Valley Fever, Mayotte, 2007-2008. Emerg Infect Dis. 2009;15:568-570.

20. Adam AA, Karsany M, Adam I. Manifestations of severe Rift Valley fever in Sudan. Int J Infect Dis. 2010;14:179180.

21. Aradaib IE, Erickson BR, Elageb RM, Khristova ML, Carroll IM, et al. Rift Valley Fever, Sudan, 2007 and 2010. Emerg Infect Dis. 2013;19:246-253.

22. Hassan OA, Ahlm C, Sang R, Evander M. The 2007 Rift Valley Fever Outbreak in Sudan. PLoS Neglect Trop Dis. 2011;5: e1229.
23. Al-Azraqi TA, El Mekki AA, Mahfouz AA. Rift valley fever in South Western Saudi Arabia: A seroepidemiological study seven years after the outbreak of 2000-2001. Acta Trop. 2012;123:111-116.

24. Ahmed B, Mamy OE, Baba MO, Barry Y, Isselmou K, et al. Unexpected rift valley fever outbreak, Northern Mauritania. Emerg Infect Dis. 2011;17:1894-1896.

25. Monaco F, Pinoni C, Cosseddu GM, Khaiseb S, Calistri P, et al. Rift valley fever in Namibia, 2010. Emerg Infect Dis. 2013; 19:2025-2027.

26. Kanouté $\mathrm{Y}$, Gragnon BG, Schindler C, Bonfoh B, Schelling E. Epidemiology of brucellosis, $Q$ fever and rift valley fever at the human and livestock interface in northern Côte d'Ivoire. Acta Trop. 2017; 175:121-129.

27. Maganga GD, Abessolo NAL, Mikala OCS, Makiala MS, N'Dilimabaka N, et al. Serological evidence for the circulation of rift valley fever virus in domestic small ruminants in Southern Gabon. Vector Borne Zoonotic Dis. 2017;17:443-446.

28. Albayrak $H$, Ozan $E$. The investigation of Pestivirus and Rift Valley Fever Virus infection in aborted ruminant foetuses in the Blacsea Region in Turkey. Kafkas Univ Vet Fak Derg. 2012;18:457-461.

29. Albayrak H, Ozan E. Seroepidemiological study of West Nile Virus and Rift Valley Fever Virus in some mammalian species (Herbivores) in Northern Turkey. J Arthropod Borne Dis. 2013;7:90-93.

30. Yılmaz V, Yıldırım Y, Coşkun N. Serological investigation of Bluetongue Virus and Rift Valley fever virus infections in sheep in Kars Province of Turkey. Van Vet J. 2015;26:119-122.

31. Gür S, Kale M, Erol N, Yapıcı O, Mamak $\mathrm{N}$, et al. The first serological evidence for Rift Valley fever infection in the camel, goitered gazelle and Anatolian water buffaloes in Turkey. Trop Anim Health Prod. 2017;49:1531-1535.

(c) 2020 Kale et al.; This is an Open Access article distributed under the terms of the Creative Commons Attribution License (http://creativecommons.org/licenses/by/4.0), which permits unrestricted use, distribution, and reproduction in any medium, provided the original work is properly cited.

Peer-review history:

The peer review history for this paper can be accessed here: http://www. sdiarticle4.com/review-history/53828 